\title{
HET ARREST VAN DE ONDERNEMINGSKAMER INZAKE DE JAARREKENING VAN MICHEL DUFOUR (HOLLAND) B.V.
}

\author{
door Prof. Mr. Drs. H. Beckman
}

\section{Inleiding}

Op 27 maart 1980 heeft de Ondernemingskamer uitspraak gedaan in de door een oud-directeur op 30 augustus 1978 aangespannen jaarrekeningprocedu. $\left.\mathrm{re}^{\prime}\right)$. De bestreden jaarrekeningen betreffen de op 30 juni 1978 vastgestelde jaarrekeningen over het boekjaar 1 september 1976 tot 1 september 1977 en over het boekjaar 1 september 1977 tot 1 januari 1978 .

Eiser, die tot 31 januari 1978 directeur van de vennootschap was ${ }^{2}$, heeft naast de vennootschap tevens de drie directieleden van de vennootschap ge dagvaard. Bij uitspraak d.d. 11 januari 1979 verklaarde de Ondernemingskamer eiser niet ontvankelijk voor wat betreft de ingestelde vorderingen tegen de directieleden, omdat op grond van de wet een jaarrekeningprocedure te. gen de rechtspersoon moet worden ingesteld (BW art. 2: 337 lid 1) $)^{3}$. Terzijde merk ik hierbij op dat een bevel van de Ondernemingskamer tot herziening van de jaarrekening zich tot de bestuurderen van de vennootschap richt (BW art. 2: 340 lid 1). In het wetsontwerp aanpassing vierde EG-richtlijn richt het bevel zich - terecht - tot de rechtspersoon.

$\mathrm{Bij}$ de reeds genoemde tussenuitspraak is de accountant ten verhoor opge. roepen. Dit verhoor heeft op 25 januari 1979 plaatsgevonden. Hierbij heeft de accountant zijn zienswijze op de materiële geschilpunten gegeven. Deze geschilpunten betreffen

- de inkoopwaarde van boten;

- de schulden aan de moedermaatschappij;

- de financieringskosten;

- de voorziening voor dubieuze debiteuren;

- de aanpassing van de jaarrekening 1977;

- de waardering van de boten.

Voor goed begrip van de geschilpunten vermeld ik dat Michel Dufour, zijnde een $100 \%$-dochter van een Franse vennootschap ten doel heeft de handel in boten en daarbijbehorende accessoires. Zij fungeert hierbij als verkoper in Ne. derland voor de door de moedermatschappij in Frankrijk geproduceerde boten.

Eiser is door de Ondernemingskamer bij tussenarrest van 25 oktober 1979 als belanghebbende erkend. Of zulks is geschied omdat hij tijdens de perioden, waarop de bestreden jaarrekeningen betrekking hebben, de directeurspositie

\footnotetext{
3) Het arrest is integraal opgenomen in Documentatie rond de jaarrehening, onder redactie van $\mathrm{H}$. Beckman en $\mathrm{O}$. M. Vol gepant alsmede in Jaarrekening znn Onderneminger, deel 3, onder redactie van P. Sanders en R. Burgert.

7) Uit het eindarrest blijkt dat volgens eiser hij directeur tot I november 1977 is geweest.

3) In dezelfde zin in de tussenarresten inzake Cobelens B.V. d.d. 26 juni 1980.
} 
innam dan wel omdat hij - zoals uit het eindarrest blijkt - provisiegerechtigde is, wordt uit de beschikbare processtukken niet duidelijk.

\section{Inkoopwaarde boten}

Eiser is van mening dat de inkoopwaarde van de boten voor een te hoog bedrag in de winst. en verliesrekening is verwerkt waardoor ook de schuld aan de moedermaatschappij te hoog is. Hij is van oordeel dat overeengekomen is dat uitgegaan moet worden van de inkoopprijs op factuurdatum. Gezien de daling in de brutomarge kan dit, naast een valuta-effect van $4 \%$, alleen veroorzaakt zijn, doordat de moedermaatschappij tussentijds de inkoopprijs voor gedaagde heeft verhoogd van reeds voor een vaste prijs verkochte schepen, terwijl dit niet was overeengekomen. Bovendien is bij de omrekening van francs in guldens van een te hoge koers uitgegaan.

Gedaagde stelt hier tegenover dat de inkoopwaarde gelijk is aan de kostprijs volgens de factuur, verhoogd met de kostprijs van de in Nederland toegevoeg. de accessoires. De facturering van boten geschiedde tot 1 januari 1977 in francs, nadien in guldens; de accessoires blijven gefactureerd in francs. Koers. verschillen tussen factuurmoment en betalingsdatum worden in de winst- en verliesrekening opgenomen. De omrekening in guldens geschiedt tegen de met de moedermaatschappij overeengekomen wisselkoers. Dit betreft de be drijfspolitiek van de moedermaatschappij, waarin deze binnen de grenzen van goed en behoorlijk koopmanschap vrij is. Voorts stelde gedaagde dat eiser ten onrechte ingaat op het commercieel beleid van de vennootschappelijke organen.

De Ondernemingskamer stelt voorop dat het in een jaarrekeningprocedure niet gaat om de verantwoording van een beleid zoals dat volgens een belang. hebbende gevoerd had moeten worden, maar om een beleid zoals dit is gevoerd. Door het aanvaarden van de prijzen door gedaagde is een beleid gevoerd dat zijn weerslag in de jaarrekening heeft gevonden met name in het behaalde resultaat. De Ondernemingskamer vervolgt dan met de belangrijke passage:

"Of en zo ja in hoeverre dit resultaat is beïnvloed door de verhouding tussen moeder. en dochtermaatschappij dient te blijken uit de uiteenzetting die in de toelichting op de jaarrekening gegeven wordt om trent de wijze van vaststelling van de prijzen voor de geleverde boten (...)".

Daar gedaagde noch gesteld heeft dat de toelichting onvoldoende is geweest noch dat in de winst- en verliesrekening andere prijzen zijn verwerkt dan uiteindelijk in rekening zijn gebracht, wordt de klacht afgewezen.

Het oordeel van de Ondernemingskamer omtrent de weergave van het gevoerde beleid past in de lijn van haar eerdere en ook latere jurisprudentie ${ }^{4}$ ). De Ondernemingskamer treedt niet in het beleid als zodanig, maar beoordeelt de presentatie in de jaarrekening. Zij waakt derhalve voor een oneigenlijk gebruik van de jaarrekeningprocedure. Wel valt op dat de Ondernemingskamer niet wijst, zoals in andere procedures, op andere rechtsmiddelen dan een beroep op de Ondernemingskamer. Van een zienswijze van de accountant op het onderhavige geschilpunt blijkt in het arrest niets.

\footnotetext{
4) Zie de arresten inzake Sekisui, Homburg, Pakhoed, Sijthoff, Vulcaansoord en HAL/Ultramarco. Zie voor de vindplaat sen van deze arresten noot 1
} 


\section{Schulden moedermaatschapplj/financieringskosten}

Eiseres heeft gesteld dat als gevolg van de te hoge inkoopprijzen van boten de schuld aan de moedermaatschappij te hoog is. Ten laste van de winst- en verliesrekening is bovendien een rentelast gebracht, berekend over deze schulden, terwijl dit niet was overeengekomen. Voorts is, al zou een rentevergoe. ding zijn overeengekomen deze tot een te hoog bedrag opgevoerd.

Gedaagde stelt dat het volstrekt redelijk en algemeen aanvaard is in dergelijke gevallen een rentevergoeding te betalen. Deze is gesteld op 7\%. Dit wordt bevestigd door de accountant. Hij merkt nog op dat de rente z.i. goed verantwoord is.

De Ondernemingskamer verwerpt de eis op dezelfde gronden als bij de klacht omtrent de inkoopwaarde van de boten. Bovendien merkt zij nog op dat uit de mededelingen van de accountant blijkt dat de rente tot een juist be. drag is verantwoord.

Ik wijs er expliciet op dat de bij de inkoopwaarde geciteerde overweging ook van toepassing is op de financieringskosten. Een uiteenzetting omtrent de be rekeningswijze en de beïnvloeding door de relatie moeder-/dochtermaatschappij kan niet worden gemist.

\section{Voorziening dubieuze debiteuren}

In de jaarrekening staat een post debiteuren van $f 1.514 .514,-$. In de toelich. ting is vermeld dat ten laste van het resultaat een post van $f$ 52.287,- aan dubieuze debiteuren is gebracht.

Eiseres is van mening dat deze post $f 32.500,-$ te hoog is, daar dit in strijd met de werkelijkheid is.

Gedaagde merkt op dat de debiteurenbewaking onvoldoende was, zodat het treffen van een voorziening noodzakelijk was. Deze is getroffen op grond van een weloverwogen beoordeling van de voorzieningen.

De accountant merkt op dat de betrokken post voornamelijk betrekking heeft op vorderingen op rechtstreekse klanten. Deze vorderingen waren ouder dan zes maanden en sommige ouder dan een jaar. Zij zijn voor $100 \%$ als du. bieus beschouwd. Acht maanden na balansdatum is pas $f 8.753$,- ontvangen. Hij meent dat tegenover afnemers geen eigendomsvoorbehoud is gemaakt.

De Ondernemingskamer verwerpt de klacht omdat uit hetgeen de accountant heeft verklaard blijkt dat de voorziening op een aanvaardbaar bedrag is vastgesteld.

\section{Aanpassing jaarrekening 1977}

Eiser acht de jaarrekening 1977, die de periode september 1977 tot en met de. cember 1977 omvat, een vertekend beeld geven. In de viermaandsperiode vin. den de grootste reclame activiteiten en alle tentoonstellingen plaats, waarvan de revenuen eerst daarna komen. De kosten zijn daarom ten onrechte ten laste van deze periode gebracht. Deze kosten zijn $f$ 13.000,- lager dan in het voor. afgaande boekjaar dat op 12 maanden betrekking heeft. Een uitleg hiervan in de jaarrekening had moeten plaatsvinden dan wel de cijfers hadden moeten worden aangepast. Ook is geen voorziening getroffen in verband met twee di. 
recteurssalarissen als gevolg van het ontslag van eiser, terwijl ook geen behoorlijke explicatie daaromtrent in de toelichting is opgenomen.

Gedaagde merkt op dat door het korte boekjaar een ander beeld door toe. vallige omstandigheden kan worden gegeven. Dit betekent geen strijd met de wettelijke voorschriften. Omtrent de afvloeiïngskosten van eiser merkt gedaagde op dat deze onder personeelskosten zijn opgenomen en gezien het geringe belang niet nader zijn toegelicht.

De accountant merkt op dat de kosten van reclame e.d. in de winst- en verliesrekening zijn verwerkt omdat het onzeker was of die kosten in baten zouden terugvloeien. Het bedrag waarover getwijfeld zou kunnen worden of activering noodzakelijk is bedroeg circa $f 8.000,-$. Er waren bovendien allerlei oncontroleerbare nagekomen kosten, zodat op grond van het voorzichtig. heidsbeginsel van activering is afgezien. Als criterium is aangehouden de periode waarin de kosten zijn geboekt en niet de periode waarop de kosten betrekking hebben. Omtrent de verhouding ten opzichte van het voorgaand verslagjaar kan hij niets zeggen omdat hij pas in augustus 1977 een opdracht tot balanscontrole kreeg.

In haar tussenarrest d.d. 25 oktober 1979 oordeelt de Ondernemingskamer dat onvoldoende is komen vast te staan

- of in het voorgaande boekjaar en eerder het systeem inhield dat kosten inzake reclame etc. ten laste van het boekjaar worden gebracht waarop zij betrekking hebben, waarin zij zijn geboekt dan wel waarin zij worden be. taald;

- welk systeem in 1977 is toegepast;

- op welk bedrag de kosten moeten worden gesteld indien niet het systeem is toegepast waarbij kosten inzake reclame etc. worden verantwoord ten laste van het jaar waarop zij betrekking hebben.

De Ondernemingskamer verzoekt daarom de accountant haar daarover nader te informeren.

De accountant verklaart blijkens het eindarrest - dat in 1977, in 1976/77 en in 1975/76 - dit laatste naar zijn indruk, omdat hij in dat jaar hiermee geen bemoeienis had de kosten van reclame etc. zijn gebracht ten laste van het jaar waarop zij betrekking hebben. Voor tentoonstellingen is daarvoor aangemerkt het jaar waarin deze plaatsvinden. Voorbereidingskosten van advertentiecampagnes worden verantwoord in het jaar van voorbereiding. Advertentiekosten zijn verantwoord in het jaar van plaatsing. Uitgegaan is van de rekeningen zoals die voor het opstellen van de jaarrekening beschikbaar waren. Er is geen verband gelegd met de mogelijke baten omdat vooraf daaromtrent geen zekerheid bestaat en achteraf ook niet altijd is aan te wijzen of de motivering tot koop alleen is ontstaan door een bepaalde advertentie, reclamecampagne of tentoonstelling. Hij merkt nog op dat de gebrekkige administratie onvoldoende aanknopingspunten bevat om alle nog niet geregistreerde verplichtingen vast te stellen. Hij vermeldt voorts dat pas eind $1978 f 9.961$ aan advertentiekosten met betrekking tot $1976 / 77$ bekend zijn geworden en dat in de loop van 1978 duidelijk is geworden dat een bedrag van $f 8.415$ aan tentoonstel. lingskosten, geboekt in 1977 betrekking had op 1978. Omtrent de verhoudingsgewijze hoge kosten over het korte boekjaar merkt hij nog op dat dit het gevolg is van de grotere publiciteit. 
Eiser stelt dat er in het verleden geen problemen waren omdat in de twaalfmaandsperiode de kosten in die periode werden geboekt en betaald. Die periode was in overeenstemming met de aard van het bedrijf van gedaagde. Ge zien de korte periode van het boekjaar 1977 hadden de tentoonstellingskosten in belangrijke mate moeten worden geactiveerd omdat zij omvatten vooruitbetaalde kosten wegens ,standhuur" e.d. Zelfs al zou dit bedrag maar $f 8.000$ bedragen, dan is dit volgens eiser van belang, omdat hij provisiegerechtigde is.

Gedaagde merkt nog op dat eiser alleen spreekt over de $f 8.415$ en niet over het door de accountant genoemde bedrag van $f$ 9.961. Zij meent dat deze pos. ten in het geheel van de jaarrekening van ondergeschikte betekenis zijn.

De Ondernemingskamer acht het toegepaste systeem in het algemeen - en ook in het onderhavige geval niet in strijd met de normen die in het maat. schappelijk verkeer als aanvaardbaar worden beschouwd. De grotere publici. teit, waardoor de daaraan verbonden kosten in het korte boekjaar slechts $f 13.000$ lager zijn dan in het voorgaande boekjaar, rechtvaardigt gezien de onzekerheid omtrent de toekomstige baten dat deze kosten of een deel daarvan niet geactiveerd worden.

De stelling omtrent het vooruitbetaalde karakter van de tentoonstellingskos. ten verwerpt de Ondernemingskamer gezien de mededelingen van de accoun. tant daaromtrent. Vervolgens merkt zij op dat niet gebleken is dat de gebreken in de administratie hebben geleid tot een onjuiste verwerking van de beschik. bare gegevens noch dat de nadien geconstateerde gebreken niet van onder. geschikte betekenis zijn. De vordering van eiser dat de jaarrekening een ver. tekend beeld geeft wordt eveneens verworpen. $\mathrm{Zij}$ merkt op dat voor een sei. zoengebonden onderneming een jaarrekening over vier maanden uiteraard niet vergeleken kan worden met een jaarrekening over twaalf maanden, maar dit betekent niet dat een jaarrekening over vier maanden geen juist inzicht in het behaalde resultaat zou geven. Of een bedrag van $f 8.000$ meer of minder winst voor eiser van materiële betekenis kan zijn, speelt geen rol, daar het in een jaarrekeningprocedure gaat om de vraag of de jaarrekening aan de wettelijke bepalingen voldoet.

$\mathrm{Bij}$ dit geschilpunt blijkt dat de accountant bij het eerste verhoor verklaart dat voor de verantwoording van de kosten van reclame etc. als criterium wordt aangehouden de periode waarin de kosten zijn geboekt en niet de periode waarop de kosten betrekking hebben. Vervolgens vraagt de Ondernemingskamer of het criterium is de periode waarop de kosten betrekking hebben, de periode waarin zij zijn geboekt, dan wel de periode waarin zij zijn betaald. Het enigszins verrassende antwoord van de accountant is: de periode waarop de kosten betrekking hebben. Uit diens nadere toelichting blijkt evenwel dat geen band met de baten wordt gelegd (matching-beginsel), maar gelet wordt op de nota's die samenhangen met ontplooide reclame-activiteiten in het betreffen de boekjaar. Ik kan hierbij niet aan de indruk ontkomen dat enigszins aan het verlangen van eiser wordt voorbijgegaan. Eiser doelt heel duidelijk op het matching.beginsel; gezien het soort bedrijf is het voor te stellen dat tot en met boekjaar 1976/77 in dit opzicht weinig problemen zullen hebben bestaan. Het zeer korte boekjaar 1977 maakt aannemelijk dat een belangrijk deel als voor. uitbetaalde kosten zou moeten worden aangemerkt. Het door de Onderne. 
mingskamer gehanteerde voorzichtigheidsmotief komt in dit licht mij niet overtuigend voor.

\section{Waardering boten}

Eiseres stelt dat de boten te laag zijn gewaardeerd omdat daarop is afgeschre. ven. Afschrijving is alleen toelaatbaar bij verouderde modellen, maar die zijn niet aanwezig. De boekwaarde dient derhalve overeen te stemmen met de inkoopprijs, of hogere waarde als gevolg van tussentijdse prijsverhogingen.

Gedaagde wijst er op dat er demonstratieboten en boten met oude hullnummers zijn. Deze kunnen niet tegen nieuwprijzen worden verkocht. De af. schrijvingen hebben plaatsgevonden op basis van individuele beoordeling van de boten. Zij merkt nog op dat opwaardering hoogst ongebruikelijk en niet ver. antwoord is.

De Ondernemingskamer acht het toegepaste systeem in overeenstemming met normen die in het maatschappelijk verkeer als aanvaard worden beschouwd. Ook een verhoging van de boekwaarde op grond van tussentijdse prijsverhogingen is in het onderhavige geval niet geboden.

Het oordeel van de Ondernemingskamer past volledig bij de waarderings. grondslag gebaseerd op historische kosten. Niet valt in te zien waarom tussentijdse prijsverhogingen in de waardering van reeds gekochte boten zou moeten doorwerken. Maar wellicht heeft eiser bedoeld - zie onder 2 . dat in de ba. lans gewaardeerd wordt tegen de z.i. oorspronkelijk overeengekomen prijzen en niet tegen de z.i. achteraf verhoogde prijzen. Dit lijkt evenwel niet erg aan. nemelijk.

\section{Afsluitende opmerkingen}

Uit het arrest blijkt zeer duidelijk het gewicht dat de Ondernemingskamer hecht aan het oordeel van de accountant. Merendeel van de stellingen van eiser worden afgewezen op grond van hetgeen de accountant heeft opgemerkt. Op zichzelf lijkt dit mij juist. De procedure maakt evenwel onvoldoende duidelijk hoe ver de accountant in zijn controle-arbeid is gegaan en welke verkla. ringen hij bij de jaarrekeningen heeft gegeven. Er blijkt alleen dat hij in augustus 1977 een opdracht tot balanscontrole heeft ontvangen.

De overweging van de Ondernemingskamer omtrent de toelichting op de verhouding moeder-/dochtermaatschappij inzake de prijsstelling (zie onder 2) en de financieringskosten (zie onder 3 ) is m.i. van algemene betekenis. De Ondernemingskamer geeft deze overweging in feite ten overvloede, daar eiser hieromtrent niets had gesteld en de Ondernemingskamer ook zonder die over. weging de vorderingen van eiser kon afwijzen. 